\title{
Rhodamine-naphthalene conjugate as a novel ratiometric fluorescent probe for recognition of $\mathrm{Al}^{3+}$
}

Jing-Can Qin, Jun Yan, Bao-dui Wang, Zheng-yin Yang*

College of Chemistry and Chemical Engineering, State Key Laboratory of Applied

Organic Chemistry, Lanzhou University, Lanzhou 730000, P.R. China

**Corresponding author. Tel.: +86 931 8913515; Fax: +86 931 8912582; e-mail:

yangzy@1zu.edu.cn (Z.Y. Yang)

Abstract: In this study, a novel chemosensor (HL) for $\mathrm{Al}^{3+}$ which contain rhodamine and naphthalene moieties has been designed and synthesized. In the presence of $\mathrm{Al}^{3+}$, the receptor exhibited a strong, increasing fluorescent emission centered at $550 \mathrm{~nm}$ at the expense of the fluorescent emission of HL centered at $520 \mathrm{~nm}$. We proposed that the addition of $\mathrm{Al}^{3+}$ triggered intramolecular fluorescence resonance energy transfer (FRET) from naphthalene to Rhodamine 6G.

Keywords: fluorescent sensor; rhodamine/naphthalene; $\mathrm{Al}^{3+}$; ratiometric; FRET/ICT

\section{Introduction}

As is known, Aluminum (Al) is the third most prevalent and abundant metal in the earth's crust [1]. Compounds of $\mathrm{Al}$ are widely dispersed and found in natural waters in food additives, in medicine etc. Nevertheless, as a non-essential element for living systems, high concentration of $\mathrm{Al}^{3+}$ can hamper plant performance, kill fish and other species in aquatic ecosystems. Even worse, the $\mathrm{Al}^{3+}$ ion existing in natural waters and most plants can enter the human body through water and foods. 
Accumulation of excessive amount of $\mathrm{Al}^{3+}$ could lead to various neurodegenerative and neurological disorders, like Alzheimer's disease, Guamanian amyotrophic lateral sclerosis and Parkinsonism dementia [2-7]. According to a WHO report, the average daily human intake of $\mathrm{Al}$ is approx. $3-10 \mathrm{mg}$. The tolerable weekly $\mathrm{Al}$ intake in the human body is estimated to be $7 \mathrm{mg} / \mathrm{kg}$ of body weight [8]. Therefore, owing to its significant impact on the biosphere and human health, it is highly desirable to develop some analytical methods for detecting and controlling the concentration levels of aluminum in the environment.

To date, several methods are available for detection of $\mathrm{Al}^{3+}$. Fluorescent chemosensor with high selectivity, sensitivity and real-time detection have attracted considerable attention. There are more and more $\mathrm{Al}^{3+}$ selective fluorescent sensors being reported in recent years [9-17]. However, most of them are mainly based on the change of single emission intensity such as PET which is easy to be affected by instrumental efficiency and environmental condition [18-22]. The design of ratiometric probes which can eliminate these deficiencies through simultaneous recording ratio signals of two emissions at different wavelengths is still challenge.

Fluorescence resonance energy transfer (FRET) is one of important mechanisms which can be applied to the design of ratiometric fluorescent probes. More specifically, FRET is a distance-dependent interaction between the electronic excited states of two different fluorophores in which excitation is transferred from donor moiety to acceptor moiety without photoemission, the transfer efficiency of the excitation primarily depend on the scope of spectral overlap between donor emission with 
acceptor absorption and the distance between donor and acceptor [23-30]. With this in mind, it can be conceived that FRET-based fluorescent ratiometric sensor is made up of naphthalene (energy donor) and rhodamine (energy acceptor) moieties.

In this thesis, we have designed and synthesized a novel FRET-based fluorescent ratiometric sensor for $\mathrm{Al}^{3+}$ in which rhodamine and naphthalene moieties are linked by glyoxal. In the absence of $\mathrm{Al}^{3+}$, the sensor exhibits fluorescence emission at 520 $\mathrm{nm}$, which is attributed to naphthalene moieties, upon addition of $\mathrm{Al}^{3+}$, the sensor shows a large fluorescence enhancement at $550 \mathrm{~nm}$ owing to the ring opened rhodamine moiety. Moreover, the presence of other relevant metal ions has almost no influence on the fluorescence enhancement and the theoretical detection limit for $\mathrm{Al}^{3+}$ can reach at $8.06 \times 10^{-8} \mathrm{M}$.

\section{Experimental}

\subsection{General information}

\subsubsection{Materials and instrumentation}

Unless mentioned otherwise, all chemicals for synthesis were purchased from commercial suppliers and used without further purification. ${ }^{1} \mathrm{H}$ NMR spectra were measured on the JNM-ECS $400 \mathrm{MHz}$ instruments using TMS as an internal standard. ESI-MS were determined on a Bruker esquire 6000 spectrometer. UV-Vis absorption spectra were determined on a Shimadzu UV-240 spectrophotometer. Fluorescence spectra were recorded on a Hitachi RF-5301 spectrophotometer equipped with quartz cuvettes of $1 \mathrm{~cm}$ path length. The melting point was determined on a Beijing XT4-100x microscopic melting point apparatus. IR spectra were obtained in $\mathrm{KBr}$ 
disks on a Therrno Mattson FT-IR spectrometer in the $4000-400 \mathrm{~cm}^{-1}$ region.

\subsubsection{Analysis}

The solutions of metal ions $(5 \mathrm{mM})$ were prepared from $\mathrm{NaNO}_{3}, \mathrm{KNO}_{3}$, $\mathrm{Ca}\left(\mathrm{NO}_{3}\right)_{2}, \mathrm{Mg}\left(\mathrm{NO}_{3}\right)_{2}, \mathrm{Al}\left(\mathrm{NO}_{3}\right)_{3}, \mathrm{CrCl}_{3}, \mathrm{FeCl}_{3}, \mathrm{FeCl}_{2}, \mathrm{CoCl}_{2}, \mathrm{Hg}\left(\mathrm{NO}_{3}\right)_{2}, \mathrm{Ni}\left(\mathrm{NO}_{3}\right)_{2}$, $\mathrm{Cu}\left(\mathrm{NO}_{3}\right)_{2}, \mathrm{~Pb}\left(\mathrm{NO}_{3}\right)_{2}, \mathrm{Zn}\left(\mathrm{NO}_{3}\right)_{2}, \quad \mathrm{LiNO}_{3}, \quad \mathrm{AgNO}_{3}, \mathrm{Cd}\left(\mathrm{NO}_{3}\right)_{2}, \mathrm{Mn}\left(\mathrm{NO}_{3}\right)_{2}, \quad \mathrm{BaCl}_{2}$ respectively, and were dissolved in distilled water. A stock solution of HL (2 mM) was prepared in DMSO. The solution of HL was then diluted 100 times under test. For fluorescence measurements, the excitation and emission slit width was $3 \mathrm{~nm}$, the emission slit width was $1.5 \mathrm{~nm}$

\subsubsection{Calculation}

The detection limit was calculated based on the fluorescence titration according to the following equation: detection limit $3 \sigma / \kappa$. where $\sigma$ was the standard deviation of blank measurements, and $\kappa$ was the slope between intensity versus sample concentration [30]

\subsection{Synthesis}

Rhodamine 6G hydrazide (Fig.S1) was synthesized according to the method reported [31]. The sensor was synthesized as shown in Scheme 1[32-36]. 

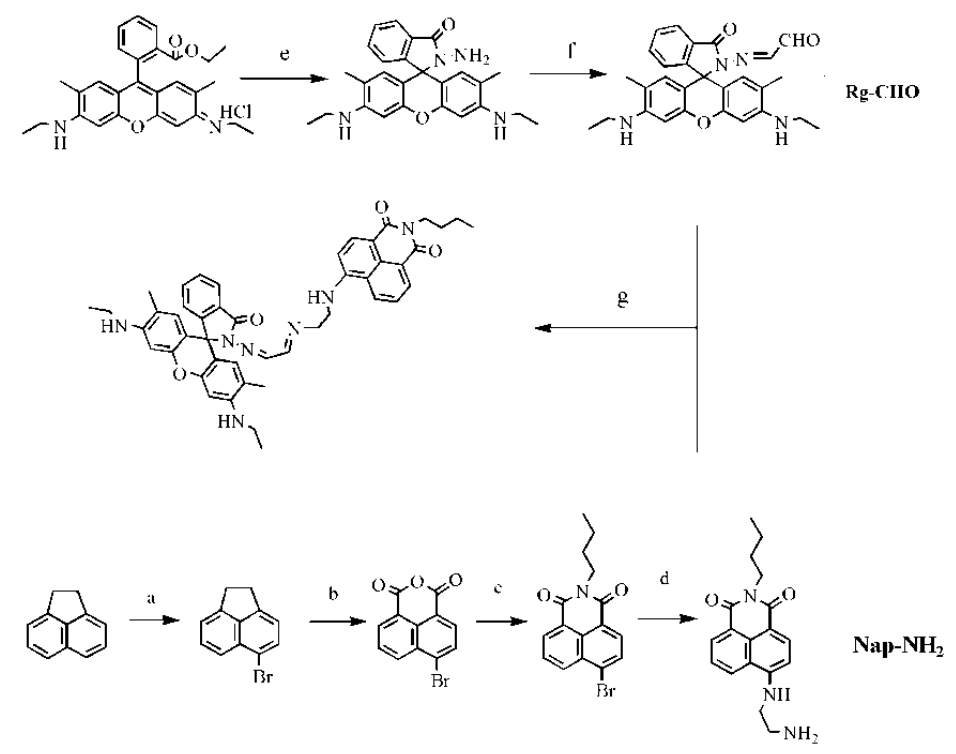

\section{Scheme1}

\subsubsection{Synthesis of compound $\mathrm{Rg}-\mathrm{CHO}$}

Rhodamine hydrazide ( $0.86 \mathrm{~g}, 2 \mathrm{mmol})$ was dispersed in $20 \mathrm{~mL}$ ethanol, excess of glyoxal $(40 \%, 1.16 \mathrm{~g}, 8 \mathrm{mmol})$ was added, and the mixture was stirred for $8 \mathrm{~h}$ at room temperature. The precipitate produced was filtered and washed 3 times with 10 $\mathrm{mL}$ cold ethanol. After drying under reduced pressure, the reaction yielded $0.77 \mathrm{~g} \mathrm{RG} 1$ as yellow solid. Yield: $76.3 \%,{ }^{1} \mathrm{HNMR}\left(400 \mathrm{MHz} ; \mathrm{CDCl}_{3}\right)($ Fig. S2 $) \delta(\mathrm{ppm})=9.40(\mathrm{~d}$, $1 \mathrm{H}, J=7.5 \mathrm{~Hz}, \mathrm{CH}=\mathrm{O}), 8.05(\mathrm{dd}, 1 \mathrm{H}, \mathrm{Ar}-\mathrm{H}), 7.54(\mathrm{dd}, 2 \mathrm{H}, \mathrm{Ar}-\mathrm{H}), 7.27$ (d, 1H, J=7.5 $\mathrm{Hz}, \mathrm{CH}=\mathrm{N}), 7.18(\mathrm{~m}, 1 \mathrm{H}, \mathrm{Ar}-\mathrm{H}), 6.37(\mathrm{~s}, 2 \mathrm{H}$, xanthene-H), 6.24 (s, 2H, xanthene-H), $3.54\left(\mathrm{~s}, \mathrm{NHCH}_{2} \mathrm{CH}_{3}\right), 3.24-3.29$ (q, J=7.1 Hz, 4H, $\left.\mathrm{NCH}_{2} \mathrm{CH}_{3}\right), 1.87(\mathrm{~s}, 6 \mathrm{H}$, xanthene- $\left.\mathrm{CH}_{3}\right) 1.29-1.32\left(\mathrm{t}, J=7.1 \mathrm{~Hz}, 6 \mathrm{H}, \mathrm{NCH}_{2} \mathrm{CH}_{3}\right)$.

\subsubsection{Synthesis of 5-bromoacenaphthene}


A solution of N-bromosuccinimide $(6.00 \mathrm{~g}, 33 \mathrm{mmol})$ in DMF $(15 \mathrm{~mL})$ was added to a DMF suspension $(25 \mathrm{~mL})$ containing acenaphthene $(5.13 \mathrm{~g}, 33 \mathrm{mmol})$ with stirring at room temperature. After being stirred at room temperature for $2 \mathrm{~h}$, then the solution was poured into cold water. The crude product was obtained via filtration, and the pure 5-bromoacenaphthene was obtained via recrystallization from ethanol. Yield : $73 \%$. Mp: $51-52{ }^{\circ} \mathrm{C} .{ }^{1} \mathrm{HNMR}$ (400 MHz, DMSO-d $)$ : (Fig.S3) $\delta(\mathrm{ppm})$ $=7.75 \sim 7.55(\mathrm{~m} \mathrm{3H}, \mathrm{Ar}-\mathrm{H}), 7.37(\mathrm{~d}, J=7.4 \mathrm{~Hz}, 1 \mathrm{H}), 7.20(\mathrm{~d}, J=7.4 \mathrm{~Hz}, 1 \mathrm{H}), 3.39$ $\sim 3.33(\mathrm{~m}, 1 \mathrm{H}), 3.31 \sim 3.25(\mathrm{~m}, 1 \mathrm{H})$.

2.2.2. Synthesis of 4-bromo-1, 8-naphthalic anhydride

5-bromoacenaphthene $(1.78 \mathrm{~g}, 7.64 \mathrm{mmol})$ was stirred with the mixture of glacial acetic acid $(31 \mathrm{ml})$ and sodium dichromate $(5.31 \mathrm{~g}, 17.81 \mathrm{mmol})$ under reflux for $5 \mathrm{~h}$. After cooled to the room temperature, then the dark green solution was poured into ice water $(65 \mathrm{~mL})$ and the residue was washed until colorless with cold water. And that the solid was stirred in $4 \% \mathrm{NaOH}$ solution $(30 \mathrm{~mL})$ at $50-55^{\circ} \mathrm{C}$. After removing the solid via filtration, the filtrate was neutralised with $5 \%$ hydrochloric acid and the white precipitate was formed. The solid obtained via filtration was then purified via recrystallization in glacial acetic acid. Yield: $36 \%$. Mp: $218-220{ }^{\circ} \mathrm{C} .{ }^{1} \mathrm{HNMR}(400$ MHz, DMSO-d $_{6}$ (Fig.S4): $\delta$ (ppm) 8.66 8.56 (m, 2H), 8.39 (d, J= 7.8 Hz, $\left.1 \mathrm{H}\right), 8.29$ $(\mathrm{d}, J=7.85 \mathrm{~Hz}, 1 \mathrm{H}), 8.06(\mathrm{t}, J=7.85 \mathrm{~Hz}, 1 \mathrm{H})$

\subsubsection{Synthesis of 4-bromo-N-n-butyl-1, 8-naphthalimide}

4-bromo-1, 8-naphthalic anhydride $(2.5 \mathrm{~g}, 9 \mathrm{mmol})$ and n-butylamine $(0.85 \mathrm{~g}$, 
$11.65 \mathrm{mmol})$ were refluxed with stirring for $12 \mathrm{~h}$ in ethanol $(100 \mathrm{~mL})$ until the mixture became clear. Then most ethanol was removed under reduced pressure and let stand overnight in refrigerator. A yellow solid was observed. Recrystallization from ethanol gave pale gray needles, Yield: $64 \%$. M.p:109-110 ${ }^{\circ} \mathrm{C} .{ }^{1} \mathrm{HNMR}(400 \mathrm{MHz}$, DMSO-d ${ }_{6}$ ) (Fig.S5): $\delta$ (ppm) 8.53 8.50 (m, 2H), 8.32 8.30 (d, $\left.J=7.9 \mathrm{~Hz}, 1 \mathrm{H}\right)$, 8.19 8.17 (d, $J=7.9 \mathrm{~Hz}, 1 \mathrm{H}), 7.98 \sim 7.94(\mathrm{~m}, 1 \mathrm{H}), 4.04 \sim 4.00(\mathrm{~m}, 2 \mathrm{H}), 1.64 \sim 1.57(\mathrm{~m}$, 2H), 1.38 1.29 (m, 2H), $0.91(\mathrm{t}, J=7.4 \mathrm{~Hz}, 3 \mathrm{H})$.

\subsubsection{Synthesis of 4-(aminoethylene)amino-N-n-butyl-1,8-naphthlimide (Nap- $\left.\mathrm{NH}_{2}\right)$}

$10 \mathrm{ml}$ of ethylene diamine was dispersed in a round- bottomed flask of $50 \mathrm{ml}$. With continuous stirring at $50{ }^{\circ} \mathrm{C}$ and within an interval of $1 \mathrm{~h}, 0.8 \mathrm{~g}(2.41 \mathrm{mmol})$ of 4-bromo-N-n-butyl-1, 8-naphthalimide was evenly added. After heating at the same temperature for $5 \mathrm{~h}$, the mixture was cooled and poured into $20 \mathrm{ml}$ of ice water. The residue was filtered and washed 5times with $10 \mathrm{~mL}$ water. Yield: $64 \% \mathrm{Mp}$ : 130-131 ${ }^{\circ} \mathrm{C} .{ }^{1} \mathrm{HNMR}\left(400 \mathrm{MHz}, \mathrm{CDCl}_{3}\right.$ ) (Fig.S6): $\delta(\mathrm{ppm}) 8.52(\mathrm{~m}, 1 \mathrm{H}), 8.43(\mathrm{~m}, 1 \mathrm{H})$, 8.13(m,1H), 7.64 7.57 (m,1 H), 6.69 6.64(m, $1 \mathrm{H}), 6.16(\mathrm{~s}, 1 \mathrm{H}), 4.16 \sim 4.12(\mathrm{~m}, 2 \mathrm{H})$, $3.33 \sim 3.16(\mathrm{~m}, 4 \mathrm{H}), 1.64 \sim 1.57(\mathrm{~m}, 2 \mathrm{H}), 1.38 \sim 1.29(\mathrm{~m}, 2 \mathrm{H}), 1.34(\mathrm{~s}, 2 \mathrm{H}), 0.91(\mathrm{t}, J=7.4$ $\mathrm{Hz}, 3 \mathrm{H})$.

\subsubsection{Synthesis of HL}

An ethanol solution $(20 \mathrm{~mL})$ of $\mathrm{Nap}-\mathrm{NH}_{2}(1 \mathrm{mmol}, 0.31 \mathrm{~g})$ was added to another ethanol $(20 \mathrm{~mL})$ containing $\mathrm{Rg}-\mathrm{CHO}(1 \mathrm{mmol}, 0.47 \mathrm{~g})$. Then the solution was refluxing for $24 \mathrm{~h}$ under stirring, the precipitate produced was filtered and washed $3 \sim 5$ times with $10 \mathrm{~mL}$ hot ethanol. After drying under reduced pressure, the reaction 
afforded HL as yellow solid. Yield: $54 \%$. M.p:245 247 ${ }^{\circ} \mathrm{C} .{ }^{1} \mathrm{HNMR}(400 \mathrm{MHz}$, DMSO-d $\left.{ }_{6}\right): \delta$ (ppm) (Fig.S7) $8.55(\mathrm{~d}, J=8.3 \mathrm{~Hz}, 1 \mathrm{H}), 8.39(\mathrm{~d}, J=7.8 \mathrm{~Hz}, 1 \mathrm{H})$. $8.19(\mathrm{~d}, J=8.5 \mathrm{~Hz}, 1 \mathrm{H}), 7.96(\mathrm{~d}, J=7.8 \mathrm{~Hz}, 1 \mathrm{H}) .7 .86(\mathrm{~d}, J=7.2 \mathrm{~Hz}, 2 \mathrm{H}), 7.78 \sim 7.76$ (m, 2H), 7.62 7.44 (m, 4H), $6.94(\mathrm{~d}, J=7.5 \mathrm{~Hz}, 1 \mathrm{H}), 6.77(\mathrm{~d}, J=8.6 \mathrm{~Hz}, 1 \mathrm{H}), 6.27(\mathrm{~s}$, 2H), 6.13(s, 2H), $4.92(\mathrm{t}, J=5.3 \mathrm{~Hz}, 2 \mathrm{H}), 3.99(\mathrm{~m}, 2 \mathrm{H}), 3.72(\mathrm{t}, J=6.1 \mathrm{~Hz}, 2 \mathrm{H}), 3.54$ $(\mathrm{q}, J=6.0 \mathrm{~Hz}, 2 \mathrm{H}), 3.15 \sim 3.06(\mathrm{~m}, 4 \mathrm{H}), 1.81(\mathrm{~s}, 6 \mathrm{H}), 1.61 \sim 1.52(\mathrm{~m}, 2 \mathrm{H}), 1.35 \sim 1.26$ $(\mathrm{m}, 2 \mathrm{H}), 1.16 \sim 1.21(\mathrm{t}, J=7.1 \mathrm{~Hz}, 6 \mathrm{H}) 0.91(\mathrm{t}, J=7.4 \mathrm{~Hz}, 3 \mathrm{H}) . \mathrm{IR}\left(\mathrm{KBr}, \mathrm{cm}^{-1}\right)$ (Fig.S8): 3439, 2949, 1686, 1551， HR-MS (Fig.S9) $[\mathrm{M}+1]^{+} \quad 762.3756$, Calcd :762.3767, $[\mathrm{M}+\mathrm{Na}]^{+}$784.3578, Calcd : 784.3587

\section{Results and discussion}

\subsection{UV-vis analysis}

To investigate the binding property of $\mathrm{HL}$ and $\mathrm{Al}^{3+}$, the changes in the absorption spectra of $\mathrm{HL}$ as a function of the concentration of $\mathrm{Al}^{3+}$ are shown in Fig. 1. The spectra of free HL showed an absorption band centered at $440 \mathrm{~nm}$, which should be assigned to the naphthalene moieties, upon the gradual addition of $\mathrm{Al}^{3+}$ (0-3.0 equiv.) to a solution of $\mathrm{HL}$, the absorption band at $440 \mathrm{~nm}$ exhibited a slightly blue shift $(\Delta \lambda=$ about $10 \mathrm{~nm})$ along with decreasing intensity, Perhaps the reasons for this phenomenon was that the bonding with $\mathrm{Al}^{3+}$ and $-\mathrm{NH}$ - changed the photophysical properties of ICT fluorophore, consequently, resulting in the reduced of the efficiency of charge transfer from -NH- to -N-n-butyl [37]. In addition, two clear isosbestic points at $430 \mathrm{~nm}, 463 \mathrm{~nm}$, were observed, which clearly indicated the presence of new complex in equilibrium with the sensor. More importantly, the characteristic 
absorption band of rhodamine at about $530 \mathrm{~nm}$ was not observed for the free HL, demonstrating its existence in spirolactam form. However, the addition of $\mathrm{Al}^{3+}$ led to appeared a new absorption band at about $530 \mathrm{~nm}$ with increasing intensity owing to the ring opened rhodamine moieties [38-39]. This indicated that the interaction of HL with $\mathrm{Al}^{3+}$ could trigger the formation of the ring-opened form of $\mathrm{HL}$ from the spirolactam form.

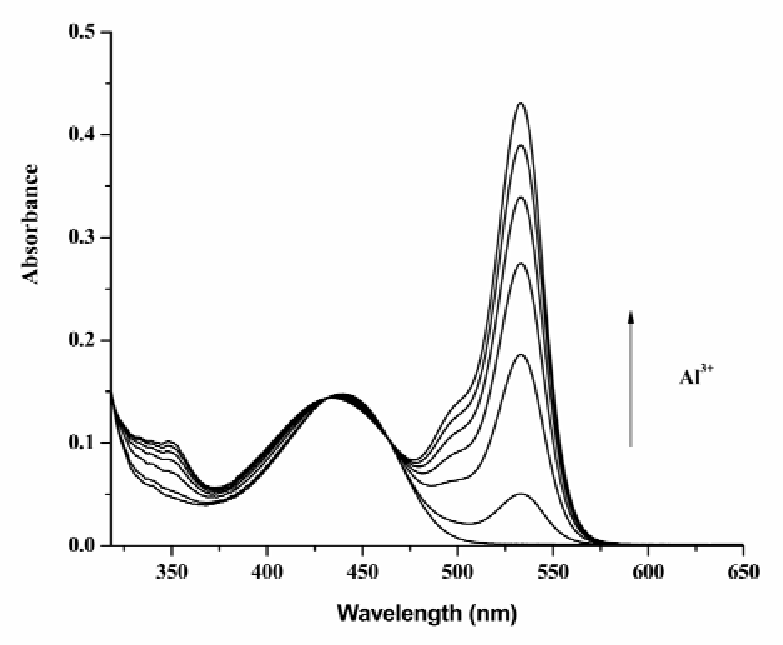

Fig. 1

\subsection{Selectivity studies and effects of metal ions}

As shown in Fig. 2, the selectivity of the sensor was investigated upon addition of several metal ions such as $\mathrm{Na}^{+}, \mathrm{K}^{+}, \mathrm{Ca}^{2+}, \mathrm{Mg}^{2+}, \mathrm{Hg}^{2+}, \mathrm{Pb}^{2+}, \mathrm{Mn}^{2+}, \mathrm{Fe}^{2+}, \mathrm{Ni}^{2+}, \mathrm{Cu}^{2+}$, $\mathrm{Fe}^{3+}, \mathrm{Co}^{2+}, \mathrm{Li}^{+}, \mathrm{Ag}^{+}, \mathrm{Ba}^{2+}, \mathrm{Cd}^{2+}, \mathrm{Zn}^{2+}$ and $\mathrm{Al}^{3+}$, the free sensor displayed fluorescence emission at $520 \mathrm{~nm}$ corresponding to naphthalene and the characteristic emission of rhodamine at $550 \mathrm{~nm}$ not appeared, which further demonstrated the rhodamine core was in the ring closed isomeric form. Upon addition of $\mathrm{Al}^{3+}$, the fluorescence 
emission (L-Al) at $500 \mathrm{~nm}$ showed a blue shift compared to the fluorescence emission at $520 \mathrm{~nm}$ (HL), combined with decreasing intensity. Moreover, the free the sensor displayed remarkable fluorescence enhancement at $550 \mathrm{~nm}$ which belong to the characteristic signal of the ring-opening of the spirolactam. The results further confirmed that the addition of $\mathrm{Al}^{3+}$ ions promoted the ring-opened reaction of the rhodamine spirolactam.

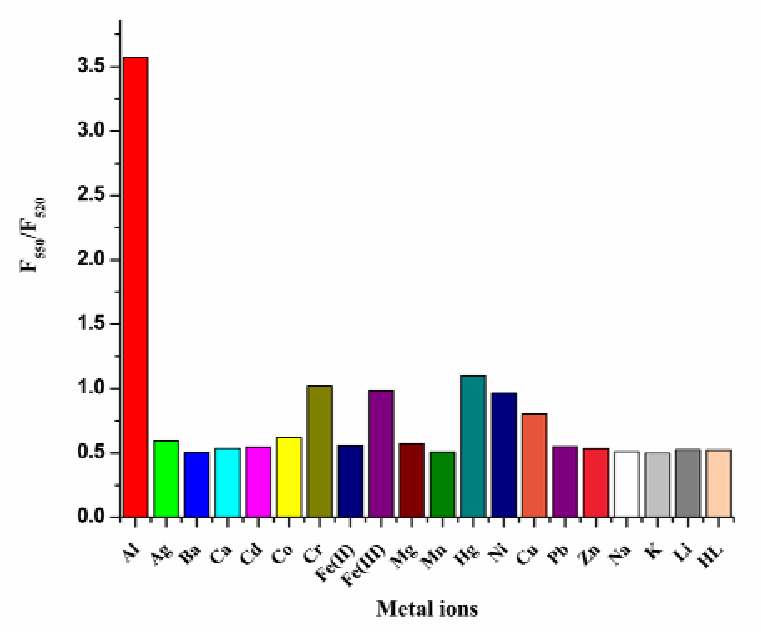

Fig. 2

In addition, in order to estimate the practical applicability of HL as a selective fluorescent sensor for $\mathrm{Al}^{3+}$, the competition experiments and fluorescent titrations were carried out. From competition experiments, as shown in Fig. 3, we found that all the coexistent metal ions had no obvious interference with the detection of $\mathrm{Al}^{3+}$. From fluorescent titrations, as shown in Fig. 4, the detection limit was calculated to be 
$8.06 \times 10^{-8} \mathrm{M}$ (Fig. S10). Thus, it meant the sensor HL, having predominant recognition and selectivity, is of a good potential in the detection of $\mathrm{Al}^{3+}$.

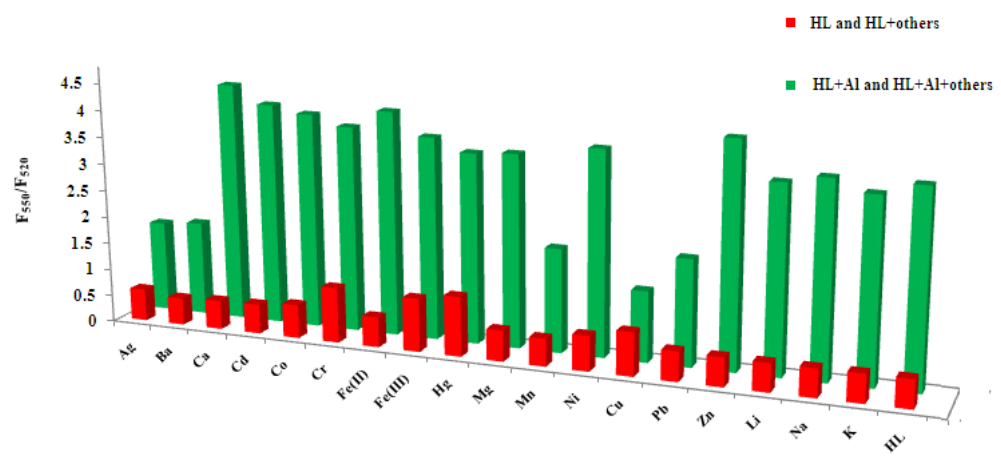

Fig. 3

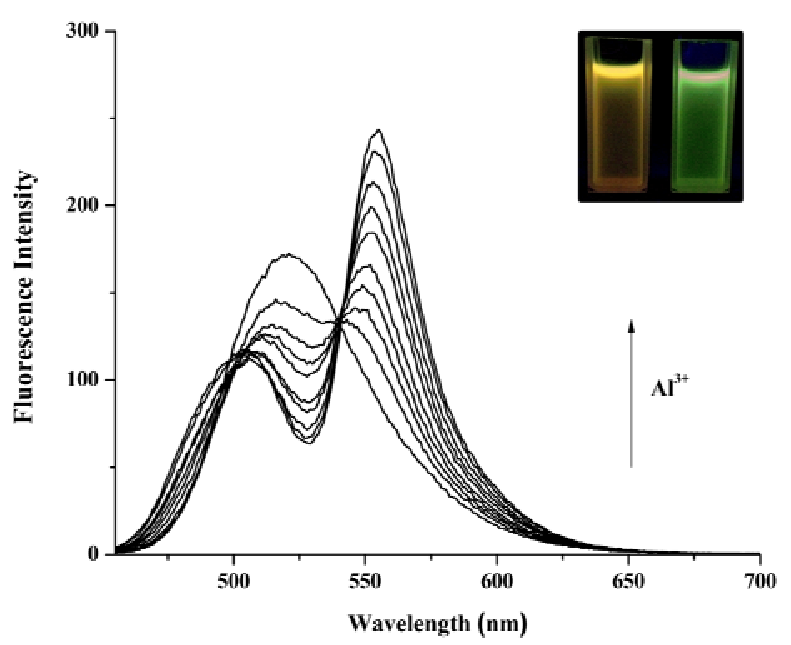

Fig. 4

3.3. The complexation of $\mathrm{HL}$ with $\mathrm{Al}^{3+}$

In order to further validate the stoichiometry of $\mathrm{HL}$ and $\mathrm{Al}^{3+}$, Job's method for 
fluorescence measurement was carried out. The total concentration of $\mathrm{HL}$ and $\mathrm{Zn}^{2+}$ was $20 \mu \mathrm{M} . \mathrm{X}_{\mathrm{L}}=\left([\mathrm{HL}] /\left(\left[\mathrm{Al}^{3+}\right]+[\mathrm{HL}]\right.\right.$. As shown in Fig. 5, the maximum point appeared at a mole fraction of 0.5 . The result has indicated that it was a $1: 1$ stoichiometry of the binding mode of $\mathrm{HL}$ and $\mathrm{Al}^{3+}$ which was further confirmed by the appearance of a peak at $\mathrm{m} / \mathrm{z} 832.98$ assignable to $\left[\mathrm{HL}+\mathrm{Al}^{3+}-2 \mathrm{H}+\mathrm{CH}_{3} \mathrm{CH}_{2} \mathrm{OH}\right]^{+}$in the ESI/MS (Fig. S11).

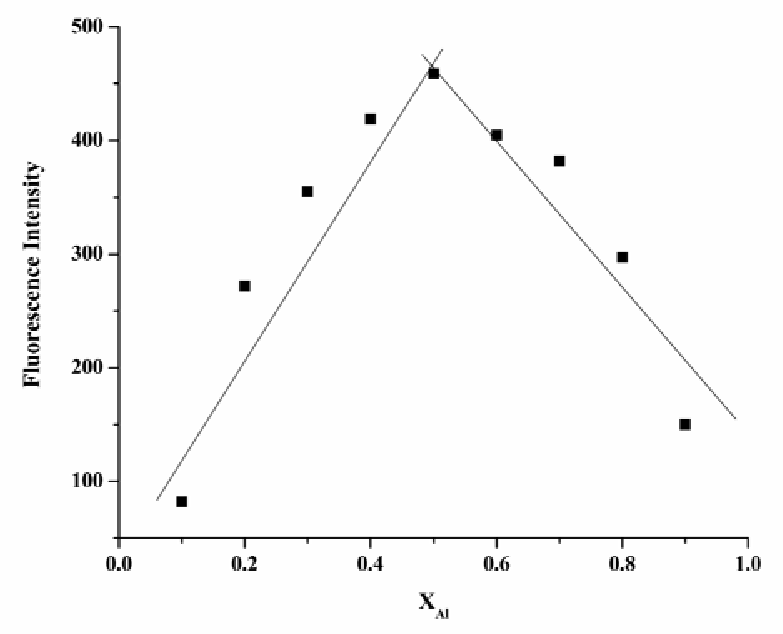

Fig. 5

Since the formation of 1: 1 ligand-metal complexes were confirmed by Job's plot analysis and ESI/MS, in combination with the fluorescence titration, the binding constant values $\left(\mathrm{K}_{\mathrm{L}-\mathrm{Al}}=2.31 \times 10^{4}\right)$ was calculated based on the modified Benesi-Hildebrand equations (Fig. S12) [40].

$$
1 /\left(F_{x}-F_{0}\right)=1 /\left(F_{\max }-F_{0}\right)+(1 / K[\mathrm{C}])\left(1 /\left(F_{\max }-F_{0}\right)\right)
$$

where $F_{0}, F_{x}$, and $F_{\max }$ were the ratio of the emission intensities (at $550 \mathrm{~nm}$ ) and the emission intensities (at $520 \mathrm{~nm}$ ) of the organic moiety considered in the absence of metal ion, at an intermediate metal ion concentration, and at a concentration of 
complete interaction, respectively, and where $\mathrm{K}$ was the binding constant concentration.

\section{The proposed mechanism}

Based on the above experiments and some reported fluorescent probes which shared some similarities to HL, the Fluorescence (or Forster) resonance energy transfer (FRET), coupled with intramolecular charge transfer (ICT) was proposed to explain the fluorescence responses of the sensor to $\mathrm{Al}^{3+}$. The sensing mechanism is schematically illustrated in Scheme 2 [26, 29, 41-43]. Up addition of $\mathrm{Al}^{3+}$, the binding with $-\mathrm{NH}-$ and $\mathrm{Al}^{3+}$ resulted in the reduced of the efficiency of intramolecular charge transfer (ICT) from -NH- to -N-n-butyl, as result, the fluorescence emission exhibited a blue shift $(\Delta \lambda=$ about $20 \mathrm{~nm})$. In addition, the fluorescence emission at $500 \mathrm{~nm}$ weaken compared to the fluorescence emission at $520 \mathrm{~nm}$ (HL) and a new emission band with a maximum at $550 \mathrm{~nm}$ appeared which were attribute to the FRET process,

namely, the addition of $\mathrm{Al}^{3+}$ triggered the ring-opening of the spirolactam, thus, the excitation energy is passed from the donor (naphthalene moiety) to the acceptor (the 'opened-up' rhodamine moiety) and then a significant enhancement of the characteristic fluorescence of rhodamine at $550 \mathrm{~nm}$ emerged at the expense of the fluorescent emission at $500 \mathrm{~nm}$. 


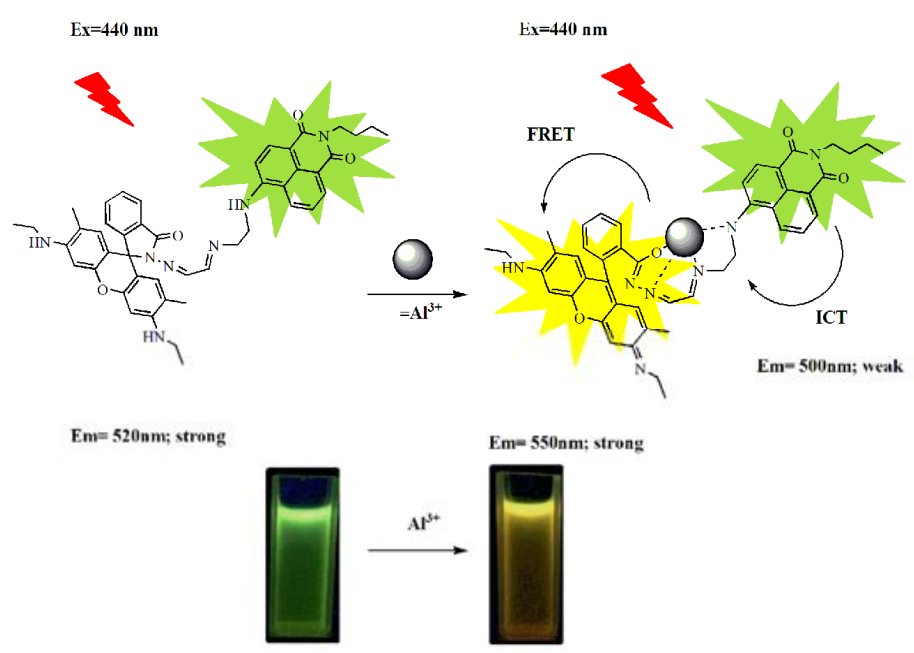

Scheme 2

\section{Conclusion}

In summary, we have successfully developed a novel ratiometric chemosensor based on an asymmetric bis-Schiff base containing rhodamine and naphthalene moieties. Up addition of $\mathrm{Al}^{3+}$, the fluorescence emission exhibited a blue shift along with decreasing intensity and a new emission appeared at $550 \mathrm{~nm}$ which were attributed to FRET, coupled with ICT. More importantly, the theoretical detection limit for $\mathrm{Al}^{3+}$ can reach at $10^{-8} \mathrm{M}$ level which is sufficiently low to enable the detection of micromolar concentrations of $\mathrm{Al}^{3+}$ in many chemical and biological systems.

\section{Acknowledgments}

This work is supported by the National Natural Science Foundation of China (81171337), Gansu NSF (1308RJZA115). 


\section{References}

[1] Sen, S.; Mukherjee.T.; Chattopadhyay, B.; Moirangthem, A.; Basu, A.; Marek, J. Analyst 2012,137, 3975-3981.

[2] Tavakoli, O.; Yoshida, H. Environ Sci Technol 2005, 39, 2357-2363.

[3] Weller, D.G.; Gutierrez, A.J.; Rubio, C.; Revert, C.; Hardisson, A. J Agr Food Chem 2010, 58, 10452-10457.

[4] Perl, D.P.; Gajdusek, D.C.; Garruto, R.M.; Yanagihara, R.T.; Gibbs, C.J. Science $1982,217,1053-1055$.

[5] Valeur, B.; Leray, I. Coord Chem Rev. 2000, 205, 3-40.

[6] Perl, D.P.; Brody, A.R. Science 1980, 208, 297-299.

[7] Fasman, G.D.; Coord Chem Rev 1996, 149, 125-165.

[8] Krejpcio, Z.; Wojciak, R.W.; Pol J Environ Stud 2002, 11, 251-254.

[9] Qin, J.C.; Li, T.R.; Wang, B.D.; Yang, Z.Y.; Fan, L. Synth Metals 2014,195 141-146.

[10] Das, S.; Dutta, M.; Das, D. Anal. Methods 2013, 5, 6262-6285.

[11] Lohani, C. R.; Kim, J.M.; Chung, S.Y.; Yoon, J.Y.; Lee, K.H.; Analyst 2010,135, 2079-2084.

[12] Han, T.Y.; Feng, X.; Tong. B.; Shi, B.J.; Chen, L.; Zhi, J.G.; Dong, Y.P. Chem. Commun 2012, 48, 416-418.

[13] Kumar, A.; Kumar, V.; Upadhyay, K. K.; Analyst 2013, 168, 1891-1897.

[14] Shi, X.Y.; Wang, H.; Han, T.Y.; Feng, X.; Tong, B.; Shi, J.B.; Zhi, J.; Dong, Y.P. J. Mater. Chem 2012, 22, 19296-19302. 
[15] He, L.; Liu, C. J.; Xin, H. Sensors Actuat Chem-B 2015, 213, 181-187.

[16] Hsieh, W.H.; Wan, C.F.; Liao, D.J.; Wu, A.T. Tetrahedron Lett 2012, 53, $5848-5851$.

[17] Tiwari, K.; Mishra, M.; Singh, V. P. RSC Adv 2013, 3, 12124-12132.

[18] Guha, S.; Lohar, S.; Sahana, A.; Banerjee, A.; Safin, D.A.; Babashkina, M.G.; Mitoraj, M.P.; Bolte, Garcia, M. Y.; Mukhopadhyaye, S.K.; Das, D. Dalton Trans 2013, 42, 10198-10207.

[19] Goswami, S. A.; Das, K.; Aich, K.; Manna, A.; Fun, H. K.; Quah, C. K. Supramol. Chem 2014, 2, 94-104.

[20] Ye, X.P.; Sun, S.B.; Li, Y.D.; Zhi, L.H.; Wu, W.N.; Wang, Y. J. Lumin $2014,155,180-184$.

[21] Sahana, A.; Banerjee, A.; Lohar, S.; Sarkar, B.; Mukhopadhyay, S.K.; Das, D. Inorg. Chem 2013, 52, 3627-3633.

[22] Qin, J.C.; Yang, Z.Y. Synth Metals 2015, 209, 570-576

[23] Wang, C.C.; Liu, Y.Q.; Cheng, J.Y.; Song, J.H.; Zhao, Y.F.; Ye, Y. E. J. Lumin. 157 (2015) 143-148.

[24] Georgiev, N. I.; Asiri, A. M.; Qusti, A. H.; Alamry, K. A.; Bojinov, V. B. Dyes and Pigm 2014,102, 35-45.

[25] Sahana, A.; Banerjee, A.; Lohar, S.; Banik, A.; Mukhopadhyay, S. K.; Safin, D. A.; Babashkina, M. G.; Bolte, M.; Garcia, Y.; Das, D. Dalton Trans. 2013, 42, $13311-13314$

[26] Q, J.C.; Yang, Z.Y.; Wang, G.Q; G.Q.; Li, C.R. Tetrahedron Lett 2015, 56, 
$5024-5029$

[27] Sen, B.; Pal, S.; Lohar, S.; Mukherjee, M.; Mandal, S. K.; Khuda, A. R.; Chattopadhyay, P. RSC Adv 2014, 4, 21471-21478.

[28] Mi, Y.S.; Liang, D.M.; Chen, Y.T.; Luo, X.B.; Xiang, J.N. RSC Adv 2014, 4, $42337-42345$

[29] Yu, C.W.; Wen, Y.Y.; Qin, X.; Zhang, J. Anal. Methods 2014, 6, 9825-9830

[30] Lohani, C. R.; Kim, J. M.; Chung, S.Y.; Yoon, J.; Lee, K. H.; Analyst 2010, 135, 2079-2084

[31] Chen, Y.T.; Mu, S.Y. Journal of Lumin. 2014,145, 760-766.

[32] Tian, M.Z.; Peng, X.J.; Fan, J.L.; Wang, J.Y.; Sun, S.G. Dyes Pigments 2012, 95, 112-115.

[33] Du, J.J.; Fan, J.L.; Peng, X.J.; Sun, P.P.; Wang, J.Y.; Li, H.L.; Sun, S.G. Org. Lett $2010,12,476-479$.

[34] Zhang, C.L.; Liu, Z.P.; Li, Y.L.; He, W.J.; Gao. X.; Guo, ZJ. Chem. Commun. $2013,49,11430-11432$

[35] Liu, B.; Tian, H. Chem. Commun., 2005, 3156-3158

[36] Wang, J.X.; Xu, Z.G.; Zhao, Y.; Qiao, W. H.; Li, Z.G.; Dyes Pigments 2007,74, 103-107

[37] Langdon-Jones, E. E.; Symonds, N.O.; Yates, S. E.; Hayes, A. J.; Lloyd, D.; Williams, R. Coles, S. J.; Horton, P.N.; Pope, S. J.A. Inorg. Chem. 2014, 53, $3788-3797$

[38] Lee, M.H.; Giap, T. V.; Kim, S. H.; Lee, Y. H.; Kang, C.; Kim, J. S. Chem. 
Commun 2010, 46, 1407-1409.

[39] Wu, Y.X.; Li, J.B.; Liang, L.H.; Lu, D.Q.; Zhang, J. G.; Mao, J. Zhou, L.Y.; Zhang, X.B.; Tan, W.H.; Shen, G. L.; Yu. R.Q. Chem. Commun 2014, 5, 2040-2042.

[40] Benesi, H.A.; Hildebrand, J.H. J. Am. Chem. Soc 1949, 71, 2703-2707.

[41] Pal, S.; Sen, B.; Lohar, S.; Mukherjee, M.; Banerjee, S.; Chattopadhyay, P.; Dalton Trans 2015,44,1761-1768.

[42] Mahato, P.; Saha, S.; Suresh, E.; Liddo, R.D.; Parnigotto,P.P.; Maria Teresa Conconi, M.T.; Kesharwani, M.K.; Ganguly, B.; Das. A. Inorg. Chem. 2012, 51, 1769-1777

[43] Zhang, J.F.; Zhou, Y.; Yoon, J. Y.; Kim, Y.M.; Kim, S. J.; Kim, J.S.; Org. Lett $2010,17,3852-3855$ 


\section{Figure captions}

Fig. 1 Changes in the absorption spectra of $\mathrm{HL}(10 \mu \mathrm{M})$ in ethanol at room temperature as a function of added $\mathrm{Al}^{3+}(0-1.0$ equiv)

Fig.2. Fluorescence spectra of HL $(20 \mu \mathrm{M})$ upon the addition of metal salts (1.0 equiv of $\mathrm{Na}^{+}, \mathrm{K}^{+}, \mathrm{Ca}^{2+}, \mathrm{Mg}^{2+}, \mathrm{Pb}^{2+}, \mathrm{Mn}^{2+}, \mathrm{Fe}^{2+}, \mathrm{Ni}^{2+}, \mathrm{Fe}^{3+}, \mathrm{Co}^{2+}, \mathrm{Hg}^{2+}, \mathrm{Li}^{+}, \mathrm{Ag}^{+}, \mathrm{Ba}^{2+}, \mathrm{Cu}^{2+}$, $\mathrm{Cd}^{2+}, \mathrm{Zn}^{2+}$ and $\mathrm{Al}^{3+}$ in ethanol $\left(\lambda_{\mathrm{ex}}=440 \mathrm{~nm}\right.$, slit widths: $\left.3 \mathrm{~nm} / 1.5 \mathrm{~nm}\right)$.

Fig. 3 Fluorescence intensity of $\mathrm{HL}$ and its complexation with $\mathrm{Al}^{3+}$ in the presence of various metal ions in ethanol, Red bar: $\mathrm{HL}(20 \mu \mathrm{M})$ and $\mathrm{HL}$ with 1.0 equiv. of $\mathrm{Na}^{+}, \mathrm{K}^{+}$, $\mathrm{Ca}^{2+}, \mathrm{Mg}^{2+}, \mathrm{Pb}^{2+}, \mathrm{Mn}^{2+}, \mathrm{Cu}^{2+}, \mathrm{Fe}^{2+}, \mathrm{Ni}^{2+}, \mathrm{Fe}^{3+}, \mathrm{Hg}^{2+}, \mathrm{Co}^{2+}, \mathrm{Li}^{+}, \mathrm{Ag}^{+}, \mathrm{Ba}^{2+}, \mathrm{Cd}^{2+}, \mathrm{Zn}^{2+}$ stated. Green bar: $20 \mu \mathrm{M}$ of HL and 1.0 equiv. of $\mathrm{Al}^{3+} ; 20 \mu \mathrm{M}$ of $\mathrm{HL}$ and 1.0 equiv. of $\mathrm{Al}^{3+}$ with 1.0 equiv. of metal ions stated in ethanol $\left(\lambda_{\mathrm{ex}}=440 \mathrm{~nm}\right.$, slit widths: $3 \mathrm{~nm}$ $/ 1.5 \mathrm{~nm})$

Fig. 4 Fluorescence spectra of the sensor HL $(20 \mu \mathrm{M})$ in ethanol upon the addition of $\mathrm{Al}^{3+}$ (0-1 equiv.). ( $\lambda_{\mathrm{ex}}=440 \mathrm{~nm}$, slit widths: $3 \mathrm{~nm} / 1.5 \mathrm{~nm}$. Inset: color of HL (right) and $\mathrm{HL}+\mathrm{Al}^{3+}$ system (left) under UV lamp.

Fig. 5 Job's plot for determining the stoichiometry of $\mathrm{HL}$ and $\mathrm{Al}^{3+}$ in ethanol $\left(\mathrm{X}_{\mathrm{Al}}=\left[\mathrm{Al}^{3+}\right] /\left(\left[\mathrm{Al}^{3+}\right]+[\mathrm{HL}]\right)\right.$, the total concentration of $\mathrm{HL}$ and $\mathrm{Al}^{3+}$ was $\left.20 \mu \mathrm{M}\right)$

Scheme1 Synthesis of HL, Reagents and conditions: (a) DMF, NBS, at room temperature, 2h. (b) glacial acetic acid,sodium dichromate, reflux, $5 \mathrm{~h}, 4 \% \mathrm{NaOH}$ at $50-55^{\circ} \mathrm{C}, 5 \% \mathrm{HCl}$, neutralization (c) EtOH, n-butylamine, reflux, $12 \mathrm{~h}$ (d) ethylene diamine , at room temperature, $5 \mathrm{~h}(\mathrm{e}) \mathrm{EtOH}$, reflux, $12 \mathrm{~h}$

Scheme 2 Proposed mechanism for detection of $\mathrm{Al}^{3+}$ by $\mathrm{HL}$ 